\title{
Islamic Political Theory during the Abbasid Government and its Implications Toward Education
}

\author{
Sudirman $\mathrm{P}^{1}$, Firdaus ${ }^{2}$, Muh.Anis ${ }^{3}$, Jamaluddin ${ }^{4}$, Suriyati ${ }^{5}$ \\ \{sudirmanuinsuka@gmail.com ${ }^{1}$ \}
}

\begin{abstract}
Tarbiyah and Teacher Training, Islamic Institut of Muhammadiyah Sinjai, Indonesia ${ }^{1,2,4,5}$
Ushuluddin and Islamic Communication, Islamic Institut of Muhammadiyah Sinjai, Indonesia ${ }^{3}$
\end{abstract}

\begin{abstract}
After the Prophet died, the succession of leadership was a difficult and tense political issue that was able to undermine the joints of the ummah that the Prophet had built firmly. This situation continues from generation to generation. Likewise with the political theory of the Abbasid era. The collapse and fall of the Umawiyah Daulah in 750 $\mathrm{AD}$ and the rise of the Abbasid Daulah were not only a change of dynasties but more than that, namely a change in social and ideological structures. The purpose of this study is to reveal the Islamic political theory of the Abbasid era in relation to the concept of education. The method of writing in this article is to use the library research method, which is carried out by studying the literature and writings that are closely related to the problems raised in this article's research. The Abbasid Daula was the longest dynasty that was able to maintain its power and bring Islam to its golden age. And this is inseparable from the role of a leader who is wise and fair to those he dreams of. And the basis of Abbasid power is religion and legal issues that do not differentiate all groups. For the Abbasids, science is very important for the progress of a country, especially concerning religious sciences and also other sciences such as linguistics and history, because scholars and scholars are born from a science. The collapse of the Abbasids resulted in Islamic education also experiencing a setback, among which setbacks were marked by the development of Sufi teachings, then a narrowing of the Islamic education curriculum which had an impact on intellectual development. On the other hand, intellectuals did not develop due to the paradigm among the Muslims at that time that the door to ijtihad had been closed.
\end{abstract}

Keywords: Jakarta politics, islam, abbasids, education

\section{Introduction}

A vision of the holy religion under Prophet Muhammad SAW is "ummatan wahidan", namely the people who are united and are not divided. The Prophet's social conditions were contrary to his vision; this made the Prophet's struggle even harder. The life of tribalism (tribalism) that was adopted by the Arabs at that time seemed as if there was no gap to find a common ground between the tribes that often contradicted one another. There is no legal umbrella, except for "natural law" which states that superiority and strong lineage become weak rulers. The Prophet's patience and persistence, in the span of approximately 23 years, succeeded in realizing this vision with the birth of the Medina state and its social institutions as reflected in the Medina declaration. At that time Islam had begun to enter the world of politics. This then becomes the hallmark of Islam that Islam is a complete and comprehensive way of life. Religion has an organic integral relationship with politics and society in all areas of Muslim life [1]. 
Politics comes from the Greek word polis which means city. Meanwhile in modern times the term politics means "the art or science of government; a science that deals with the principles of regulation and supervision of the people who live in society "while the term 'state' means the state comes from the Latin word status, according to Wester's Dictionary, a state is a number of people who live in a certain area permanently, politically organized under a government. which is sovereign, completely free from outside control and has coercive power in order to maintain order in society [2].

After the Prophet's death, the succession of leadership was a difficult and tense political problem that was able to undermine the joints of the ummah that had been firmly built by the Prophet [3]. This situation continues from generation to generation. Through quite heated discussions at the Bani Sa'idah Hall, the Muslims finally agreed to choose Abu Bakr as the community leader (the first caliph) after the Prophet. This was the first shura system that resulted in the decision to appoint a caliph after the death of the Prophet. This is also the basis of Sunni ideology politics in the future. History records that the first four successors of the Prophet were just and righteous leaders. They are ideal leaders, traditions from the teacher for the advancement of Islam and its ummah. Because of that they are given the title "who gets guidance on the straight path" (al-khulafah ar-rashidin) [4].

Abbasid rebellion, which brought Abu al-Abbas as-Saffah to the throne of the caliph and the death of the last Umayyad caliph [5]. The fall of the Umayyah can be traced to the growing strength and disappointment of the mawali or non-Arab Muslims, the breakdown of the unity of the Arab tribes, and the disappointment of most members of the general religious movement, and the spread of longing for a political savior, a charismatic leader. These four factors represent the various forces at work in the empire, and the combined victory of these forces will undoubtedly bring about major changes in the social and political structure. At the same time, support for the Abasiyah also came from many heterogeneous elements so that some of the extremists among them would surely feel dissatisfied [6].

The discontent of non-Arab Muslims played a major role in the downfall of the Umayyads as their numbers continued to grow. The Abbasids were thus forced to eliminate these causes of discontent, not only in return for their contribution to the victory of the dynasty, but also for their importance in the caliphate. Non-Arab Muslims want equality with Arabs. They are no longer second-class citizens who suffer as deprivation, but want to enjoy all the privileges of the Arab people, not only in the economic sphere [6].

When the Umayyads came to power, Mu'awiyah ibn Sufyan opened a new chapter of an ummat leadership determined by lineage, descent and ethnicity [7]. This means that what the Prophet aspired to do to distribute justice through Islam to the entire ummat without commanding lineage or ethnicity was eroded again. The Umayyads were born and started with historical scars that still hold the bodies of the Muslim community. Massive expansion was carried out by the leader of the Umayyad Daula to spread Islam, perhaps from there the conception of jihad and war is increasingly difficult to remove.

As a means of revelation, Muhammad not only brought the doctrine of the means to draw closer to God to mankind, but also social ethics which neutralized many elements that were considered "natural" only to humans as social creatures. In Medina he (Muhammad) had formed a sacred community, a brotherhood of Muslims in the world but did not love the world. The first four caliphs were best at defending this ideal. With the rule of the Umayyad dynasty, it began to strike at its roots, that's the case for Muslim historians, the process of securalization which has never been restored since then. Mu'awiyah achievement does not create balance, because that achievement is the achievement of the "emperor" because of that he is often referred to as the Muslim emperor [8]. 
During the Abbasid era a system of government was built, of course, it could not be separated completely from the joints built by the previous empire. In their propaganda, they want to uphold justice based on equality of rights, restore the condition of the Muslims as in the time of the Khulafah al-Rashidin because the Umayyads considered them to have deviated. Likewise, Muslims are very hopeful about the big changes made by the Abbasids.

How were the Abbasids able to realize the hopes of Muslims? This paper will describe the Abbasid dynasty, especially those related to the political aspects as well as those that surround it. Because in historical records the Abbasids were the longest dynasty that was able to maintain their power and bring Islam to a golden age.

\section{Method}

The method of writing in this article is to use the library research method, which is done by studying the literature and writings that are closely related to the problems raised in the research of this article. this is intended to obtain complete information and determine actions to be taken in scientific activities.

This research uses descriptive analysis method, which describes in depth what it is objectively in accordance with the data collected. And relevant past research that others have already done. This research is philosophical in nature, namely research that describes and reports a situation, a certain object is then analyzed more critically

\section{Results and Discussion}

\subsection{The history of the abbasid establishment}

The Abbasid Daula was founded by Abdullah ibn al-Abbas from the Hashim group in Mecca. He came from the family of the Prophet's uncle. Its power lasted for a fairly long period of time, from $132 \mathrm{H} / 750 \mathrm{M}$ to $656 \mathrm{H} / 1258 \mathrm{M}$ The Abbasid dynasty was a caliphate that replaced the Ummayyah dynasty in Damascus, after successfully overthrowing this power in $750 \mathrm{M}$ [9]. The Abbasids held fast to their rule until it was crushed by the Mongol Invasion on $656 \mathrm{H} / 1258 \mathrm{M}[10]$.

Towards the end of the Umawiyah Daula I [11], There are various kinds of chaos which are caused by:

- Continuous oppression of the followers of Ali and Bani Hashim in general.

- To humiliate non-Arab Muslims so that they are not given the opportunity to be in government.

- Offensive violations of Islamic teachings and human rights.

Therefore, it is logical for the Bani Hashim to seek a way out by establishing a secret movement to overthrow the Umawiyah daulah. This movement collects [11]:

- Descendants of Ali (Alawiyin) the dreamer Abu Salamah.

- Descendants of Abbas (Abbasid), the leader Ibrahim al-Iman.

- Descendants of the Persian nation of the leader Abu Muslim al-Khurasany.

Daulah Umawiyah and Daulah Abbasiyah there are several differences, including: 
- Umawiyah still maintains and glorifies the pure Arabs, both the caliphs or employees and their people. As a result, there was a kind of caste in a country that was still pure Arab, occupying the highest class besides mixed descent and foreigners called Mawali. The Abbasids were not that strict anymore, only the caliphs were from Arabia so that the term Mawali disappeared; even the ministers, governors, commanders and employees were appointed from the Mawali group, especially the Persian group.

- The capital of Umawiyah, Damascus, is still characterized by the tradition of ignorance, sprinkled with Byzantine and Persian splendor. Meanwhile, the Abbasid capital, Baghdad, was thoroughly immersed in Persian and became an international city.

- Umawiyah was not the Prophet's family, whereas the Abbasids based the caliphate on the Prophet's family (Abbas was the Prophet's uncle).

- Umawiyah culture is still in the Arabic style of ignorance with the splendor of poetry and storytelling. Meanwhile, Abbasid culture opened the door to all advanced cultures so that Arab, Persian, Greek, and Hindu cultures were assimilated.

- The Caliph Umawiyah was fond of verse and kasidah as in the days of the splendor of the Arabic literature of ignorance. Meanwhile, the Abbasid caliph was fond of science as a result of which science became the center and even reached its maturity [11].

\subsection{Abbasid political movement}

Before it officially became an Islamiyah daulah, the Abbasids were a political movement that succeeded in seizing the Umayyad political rivals to fight under one "ahlu bait" flag with a campaign to destroy the Umayyad Dynasty which was considered to have come out of Islamic teachings [12]. The originator of the Abbasid movement was Ali bin Abdullah Bin Abbas who was later succeeded by his son Muhammad bin Ali (Syi'atuh Abbas) [13]. Among the steps taken was to send da'i disguised as traders or regional pilgrims, forming resistance factions in Humaimah, Kufah and Khurasan, enforcing the idea of equality between Arabs and non-Arabs [14].

According to Atho Muzakkar there are four theories behind the rise of the Spirit of Bani Abbas, namely [12]:

- Theory of racial factionalism (National Grouping). Daulah Bani Umayyad is a daulah that concerns the interests of the Arabs and neglects or excludes the interests of the non-Arabs (mawali) even though they have entered Islam, so that the mawali people feel disillusioned and gather forces to overthrow the government of the Umayyads.

- Sectarian Factionalism Theory (Grouping of Religious Groups). The Shiites were political opponents of the Umayyads who considered seizing the caliphate from the hands of Ali ibn Abi Talib. The Shiites held a coalition with the Abbasids led by Ali bin Muhammad, and the khawarijs continued to push to overthrow the existing government.

- Qabilah Factionalism Theory (Tribal). The great and influential tribalism of the Umayyad dynasty was the Mudhariyah (Northern Arab tribe) and Yamaniah (Southern Arab tribe). During the Umayyad Dynasty if one tribe supported the caliphate, then the other tribe acted as the opposition. This conflict continued to spread and extend beyond the boundaries of tribal areas to the khurasan, because previously the Abbasids had controlled Khurasan in anetorial and political way.

- The Theory of Regional Injustice and Disparity The limpness in making economic policy, especially in paying taxes and land management rights in newly conquered territories is the cause of injustice committed by officials during the Umayyad 
caliphate. This led the citizens to rebel against daulah umayyads because of perceived economic discrimination.

The four theories combined will get an idea that the area of Islamic rule along with the citizens of the country converted to Islam but not accompanied by economic justice in terms of paying taxes and paying farmland rent. In addition, each new conquest is also accompanied by data of relatives of relatives of the soldiers or indeed deliberately brought to settle in a conquered area and the relatives of these soldiers who cultivate agricultural land but also pay the rent of land of the same size as the tax of the conquered population who have not converted to Islam.

On the other hand, the conquered populations are also required to follow militarization (military education) but they get unfair treatment, namely soldiers from Arab tribes get salaries and benefits in the form of land that is not taxed, and if the soldiers are from the mawali and non-Muslims they are only paid and do not get benefits.

The process of Islamization of the indigenous peoples of the conquered country was not accompanied by the attention of the Umayyad government to send clerics to the conquered country as religious teachers, quite the contrary the opposition movement (Syi'ah and khawarij) that sent clerics throughout the conquered country and this as a means to build a power base to overthrow the Umayyad Dynasty [12].

For about 50 years the Abbasids were an underground movement. After Imam Muhammad bin Ali died (125 H / $742 \mathrm{AD})$ and replaced Ibrahim bin Muhammad changed his movement is open by holding a rebellion against the Umayyads. The insurgency was gained by Abu Muslimin al-Khurasani, who received a lot of support from mostly Arabs, especially disillusioned citizens living in Merv, Yemen's Arab group, the Mawali and shi'ite groups. The war took place on the banks of the Tigris river directly facing the caliph Marwan II (Marwan bin Muhammad) with victory on the side of Abu Muslim al-Khurasany, so Marwan II fled with his troops to Egypt to seek refuge, but was still pursued by abbasid forces led by Abdullah bi Ali, Abu Abbas's uncle. So there was a war on the Zab river located between the town of Mousul Samarrn in Late Jumadil 132 H / 750 AD. Finally he was killed by Shaleh bin Ali bin Abdullah (son of Uncle Abu Abbas), with this ended the Umayyad Dynasty in power approximately 90 Years and began a new power that is the Abbasid Dynasty[13].

The politics run by the Abbasid daulah are:

- Power is fully held by the caliph who maintains pure Arab ancestry assisted by the Vizier, Ministers, Governors and commanders and officials from various nations and at this time who are being widely appointed from the Mawali faction of Persian descent.

- The city of Baghdad as a city of state, became a center of political, social and cultural activities, made an international city that is open to all nations and beliefs so that gathered there arabs, Turks, Persians, Romans, Kurds and so on.

- Science is seen as a noble and noble thing. The caliphs and other authorities opened the widest possibilities for the advancement and development of science. The caliphs themselves are generally scholars who love science, respect scholars and glorify poets.

- The depravedness of thinking is fully recognized. At that time reason and mind were freed completely from the shackles of taklid, a condition that causes people to be very free to express opinions in all fields including religion, philosophy, worship and so on.

- Ministers of Persian descent are given full rights in running the government so that they play an important role in fostering Islamic civilisation. they love science very much and make their wealth to improve people's intelligence and advance science[11]. 


\subsection{The political period of the abbasid daula}

The third period in the basic drama of Islamic politics opened with the role of caliph Abu al-Abbas who proclaimed the establishment of Daulah Abbasiyah in the Year $132 \mathrm{H} / 750 \mathrm{AD}$. At the time of his penobata at the Kuffah Mosque, he called himself al-Saffah (blood-eater) who eventually became a nickname. It's a bad start where his power depends on the murder he's used as his political wisdom [7].

The basis of the government was successfully laid by Abu Jafar Al-Mansur, the second caliph after Abu Abbas. Al-Mansur put the laws of the state with his mind, a personal legal system bound by the sharia of the Qur'an. Al-Mansur once said, "it is the sultan of God on his earth. I lead you with his gifts, direction and support. I guard and do it with his will and desire. And I gave it to him with his permission [15].

Abbasid dynasty is the longest dynasty capable of bringing Islam to its peak of glory, is the golden age in the course of Islamic history (750-1258) [16]. Judging from the process of forming the Abbasids was established on the basis of the following:

- Unity to deal with divisions arising from the previous dynasty.

- Universal and not based on tribal aspects.

- Politics and administration as a whole, not appointed on the basis of nobleness.

- Common relationships in law for every Islamic society.

- The government is moderate Muslim; The Arab race is simply seen as one part-of the other races.

The right to rule as heirs of the prophet is still in their hands [17]. Under abbasid rule the world of science experienced a golden age especially in the first two hundred years. Thanks to the leeway and support of the rulers the activities of scientists soared. So many written works from scientists in various branches of science, both religious and general. This caused concern and desire among scientists to study the problem of statehood rationally which then gave birth to Islamic thinkers who had successfully systematically compiled the caliph of the Abbasids and ran the wheels of government.

Hedonism and a secular system of government are believed to be the triggers for the retreat of the Abbasid caliphate. This condition began to be felt from the leadership of Caliph Al-Mu'ti to Al-Mu'tasim (945-1258 AD). As a result, the central caliphate weakened a number of regional rulers (governors) to look at the autonomous. Governors based in the western Baghdad region are trying to disobey the central caliphate in Baghdad. It was in such turmoil that Hulaghu Khan's army with the Tartar army in AD 1258 destroyed Baghdad [18].

\subsection{Development of science during the abbasid period}

$\mathrm{X}$ century $\mathrm{AD}$ is called the century of development daulah Islamiyah where the Islamic world, ranging from Cordove in Spain to Multan in Pakistan, experienced development in all fields, especially in the fields of science, technology and the arts. The Islamic world at that time was advanced, triumphant, prosperous; Otherwise the Western world is still in a dark, stupid, and primitive state. The Islamic world has been busy conducting investigations in laboratories and observatories; The Western world is still preoccupied with the hourly and the gods. This is because the religion under the Prophet Muhammad has caused an impetus to foster a new culture, namely Islamic culture. The encouragement first drove the creation of sciences in the field of religion (science naqli), emerging religious sciences in various fields. Then when Islam came out of the Arabian Peninsula, they found the Greek treasury [19]. 
It is told by Syed Amir Ali (Islamic Culture) quoted by Musyrifah Sunanto in his book Classical Islamic History, that the origin of the arrival of Greek culture is greek philosophers who fled their country because they were chased by their king due to madzhab differences. In fact, they were systematic constituents of science, but when Greece was colonized by the Romans, its Christian kings did not tolerate it. The reign of King Constantine the Great (d. 366 A.D.), the library, founded by a liberal weaning king, was dissolved or destroyed, knowledge regarded as cursed magic, philosophy and science exterminated [11].

The Intellectual Awakening Movement was marked by the project of translating Works in Persian, Sanskrit, Syrian, and especially greek-speaking Arabic, the establishment of a center for the development of science and library namely Bait al-Hikmah, and the establishment of sects of science and religion as the fruit of freedom of thought [20].

The movement to build knowledge was largely pioneered by the caliph Ja'far al-Mansur. After he founded the city of Baghdad (144 H / 762 AD) and made it the capital of the country. He attracted many scholars and experts from different regions to come and live in Baghdad. It stimulates the bookkeeping efforts of religious sciences, such as fiqh, tafsir, tawhid, hadith, or other sciences such as language and historical sciences [20].

\section{Conclusion}

The beginning of the appearance of the Abbasids was a political movement that propagated the rescue and straightening of the Muslim Ummah government (Bani Umayyah) who were considered to have kept Islamic teachings. Finally it succeeded, under Abu Abbas as-Saffah the Abbasids were proclaimed to be Muslims in $750 \mathrm{AD} / 132 \mathrm{H}$, after succeeding in overthrowing the Umawiyah (Marwan bin Muhammad). The Abbasids were able to lead Muslims for approximately 5 centuries, ranging from 750 to $1258 \mathrm{AD}$, and were able to bring Islam to the peak of glory that became a qibla for the world of science, especially during the caliph alMa'mun. The development of science during the Abbasid period was very advanced, successful and rapidly developing. Especially religious sciences, such as fiqh, tafsir, tauhid, hadith, and other sciences such as language and historical sciences. So that the religion under the Prophet Muhammad has caused an impetus to foster a new culture that is Islamic culture.

The collapse of the Abbasids could result in Islamic education also experiencing a setback, among which setbacks were marked by the development of Sufi teachings, then a narrowing of the Islamic education curriculum which had an impact on intellectual development. On the other hand, intellectuals did not develop due to the paradigm among the Muslims at that time that the door to ijtihad had been closed. With the collapse of the Abbasid empire there was no longer any possibility of telling the history of the Middle East from a central point of view. All of these things resulted in the emergence of a new pattern in the Islamic world which was separated by regions which became a model for the further development of Islam and this we still feel today.

In the author's analysis, there are several things that need to be a big note in the history of the leadership of the Abbasid Daula, and I think these can be important lessons that need to be applied in the Islamic world today, especially in the world of education. First, the Khilafah or al-Imamah is an important institution in Islam. This term refers to the state or government. The Khilafah is the mother of all institutions, without which all institutions lose their principles and support. Internally, the caliphate is the implementation of sharia, the comprehensive application of the individual and the institution is the first means of bringing about justice. Externally the caliphate is responsible for the welfare and peace of the ummah, is responsible for ordering 
people to submit to it, and is also responsible for a new world order that is peaceful and just on earth. And this is what the Abbasid daulah did during his leadership. Second, the Abbasid Daula was the longest dynasty that was able to maintain its power and bring Islam into a golden age. And this is inseparable from the war of a leader who is wise and fair to those he dreams of. And the basis of Abbasid power is religion and legal issues that do not differentiate all groups. Third, for the Abbasids, science is very important for the progress of a country, especially concerning religious sciences and also other sciences such as linguistics and history, because scholars and scholars are born from a science.

\section{Acknowledgement}

During the writing of this article the author is very grateful to the Muhammadiyah Sinjai Institute of Islam as a forum for writers in their work

\section{References}

[1] J. L. Esposito, Identitas Islam Pada Perubahan Sosial Politik, 1st ed. Jakarta: PT. Bulan Bintang, 1986.

[2] A. Syafi'I Maarif, Islam dan Masalah Kenegaraan, Studi Tentang Peraturan Konstitutiante. Jakarta: LP3ES, 1996.

[3] H. Nasution, Islam Rasional Gagasan dan Pemikiran. Bandung: Mizan, 1996.

[4] Ali Mufrodi, Islam di Kawasan Kebudayaan Arab. Jakarta: Logos Wacana, 1997.

[5] M. D. Rais, Teori Politik Islam. Jakarta: Gema Insani Press, 2001.

[6] W. M. Watt, Kejayaan Islam, Kajian Kritis Dari Tokoh Orentalis. Yogyakarta: Tiara Wacana, 1990.

[7] Mahsunah, Sejarah Politik Islam; Panggung Pergulatan Politik Kekuasaan dari Timur Tengah Hinggah Asia. Yogyakarta: Nusantara Prees, 2011.

[8] C. L. G. E. (Hasan A. Hakim), Menghampiri Islam (Mata Baru Menumbuhkan Imam AutentikProgresif). Jakarta: PT. Serambi Ilmu Semesta, 2005.

[9] A. Murtopo, "Politik Pendidikan Pada Masa Daulah Abbasiyah (Kasus Madrasah Nizhamiyah Di Baghdad)," Ta'dib J. Islam. Educ., vol. 19, no. 02, pp. 313-332, 2014.

[10] S. Omer, "The effect of the Abbasids' political disintegration on the architectural development of The Prophet's Mosque,” Al-Jami'ah, vol. 54, no. 1, pp. 175-202, 2016.

[11] M. Sunanto, Sejarah Islam Klasik, Perkembangan Ilmu Pengetahuan Islam. Jakarta: Prenada Media, 2004.

[12] M. A. Muzakkar, Pendekatan Studi Islam dalam Teori dan Praktek. Yogyakarta: Pustaka Belajar, 1998.

[13] M. K. Abdullah, Sejarah Pemikiran dan Perdaban Islam. Jakarta: Pustaka Book Publiser, 2009.

[14] A. Tohir, Perkembangan Perdaban Islam di Kawasan Dunia Islam. Jakarta: PT. Raja Grafindo Persada, 2004.

[15] Y. Al-Isy, Dinasti Abbasyiah ter. Arif Muhammad. Jakarta: Pustaka Al-Kausar, 2009.

[16] Ajid Thohir, Perkembangan Peradaban di Kawasan dunia Islam. Jakarta: PT. Raja Grafindo Persada, 2004.

[17] P. K. Hitti, Sejarah Bangsa Arab. Serambi Ilmu Semesta, 2004.

[18] A. Y. Anshaori, Menuju Khilafah Islamiayah; Perjuangan Ikhwanul Muslimin. Yogyakarta: Siyasat Prees, 2008.

[19] Oemar Amin Husain, Kultur Islam. Jakarta: Bulan Bintang, 1964.

[20] S. Mahroes, "Kebangkitan Pendidikan Bani Abbasiyah Perspektif Sejarah Pendidikan Islam," J. TARBIYA, vol. 1, no. 1, pp. 77-108, 2015. 